\title{
Progress and perspectives in aquatic primary productivity: introduction
}

\author{
Ilana Berman-Frank ${ }^{1}$, Tom Berman², Hugh MacIntyre ${ }^{3}$ \\ ${ }^{1}$ Mina and Everard Goodman Faculty of Life Sciences, Bar-Ilan University, Ramat-Gan 52900, Israel \\ ${ }^{2}$ Kinneret Limnological Laboratory, PO Box 447, Migdal 14950, Israel \\ ${ }^{3}$ Dauphin Island Sea Lab, 101 Bienville Blvd, Dauphin Island, Alabama 36528, USA
}

Accurate determination of gross photosynthetic carbon fixation, respiration and other loss processes from primary producers in aquatic environments is fundamental to understanding how these ecosystems function. The complex effects of rising atmospheric $\mathrm{CO}_{2}$ concentrations and global warming on aquatic systems highlight the need for progress. Advanced technologies provide new measurements of these processes from molecular to global scales and challenge us to modify and refine our concepts of aquatic systems.

The Group for Aquatic Primary Productivity (GAP) is a working group of the International Society for Limnology (SIL) and the International Association for Ecology (INTECOL). GAP workshops bring scientists and students of disparate backgrounds and experience together to work in diverse aquatic environments and to share innovative ideas and expertise. The workshops comprise hands-on, joint field and lab experiments to which participants bring state-of-the-science equipment and methodology to test comparability and reliability.

The 8th GAP International Workshop held in Eilat (Israel) in April 2008, attracted over 90 registered participants from across the globe. The Eilat venue provided a variety of sites to test theories and experimental approaches, such as fast rate repetition rate and pulse amplitude modulated fluorometry, emission spectroscopy, membrane-inlet mass spectrometry, microelectrodes and planar optodes. The experiments were carried out in the Gulf of Aqaba (Fig. 1), which has oceanic and oligotrophic 'blue desert' waters, hyperdense populations of algal symbionts in fringing corals, seagrass meadows and seaweed beds. Dense macroalgal cultures were available nearby at the Israel National Center for Mariculture (Fig. 1). The desert location also provided an opportunity to study extreme environments in the form of saltern ponds that harbor a diverse population of photosynthetic organisms (Fig. 1).

The first 2 days of the meeting were dedicated to invited keynote presentations and planning, after which the workshop shifted into 'experimental mode'. There were 7 workgroups focusing on (1) the open ocean, (2) phytoplankton primary production and respiration, (3) photosynthesis and respiration in saltern ponds, (4) coral reefs, (5) bioreactors, (6) macroalgae and (7) seagrasses.

Seven of the keynote papers from the workshop are presented in this Special Issue. These include overviews of net and gross photosynthesis and photoacclimation (Beardall et al. 2009, Dubinsky \& Stambler 2009); evaluations of methodologies used to estimate productivity $-{ }^{14} \mathrm{C}$ uptake (Marra 2009), ${ }^{17} \mathrm{O} /{ }^{16} \mathrm{O}$ and ${ }^{18} \mathrm{O} /{ }^{16} \mathrm{O}$ ratios (Luz \& Barkan 2009), and active fluorescence (Suggett et al. 2009a); a discussion of the relative roles of anoxygenic and oxygenic phototrophy and chemolithotrophy in global productivity (Raven 2009), and a review of the biota of hypersaline saltern ponds (Oren 2009).

Contributions arising from experiments conducted at the workshop are presented. Of these, 4 (Bar-Zeev et al. 2009, Iluz et al. 2009, Lis \& Shaked 2009, Suggett et al. 2009b) describe experimental work based around a storm event that led to a transient bloom of phytoplankton in the oligotrophic Gulf of Aqaba. A further 4 (Prášil et al. 2009, Sørenson et al. 2009, Warkentin et al. 2009, Woelfel et al. 2009) describe microbial diversity and activity across the sharp salinity and oxygen gradients in saltern ponds. Finally, 2 studies (Kromkamp et al. 2009, Sukenik et al. 2009) address short-term changes in photosynthetic responses in mass cultures of Nanochloropsis. 

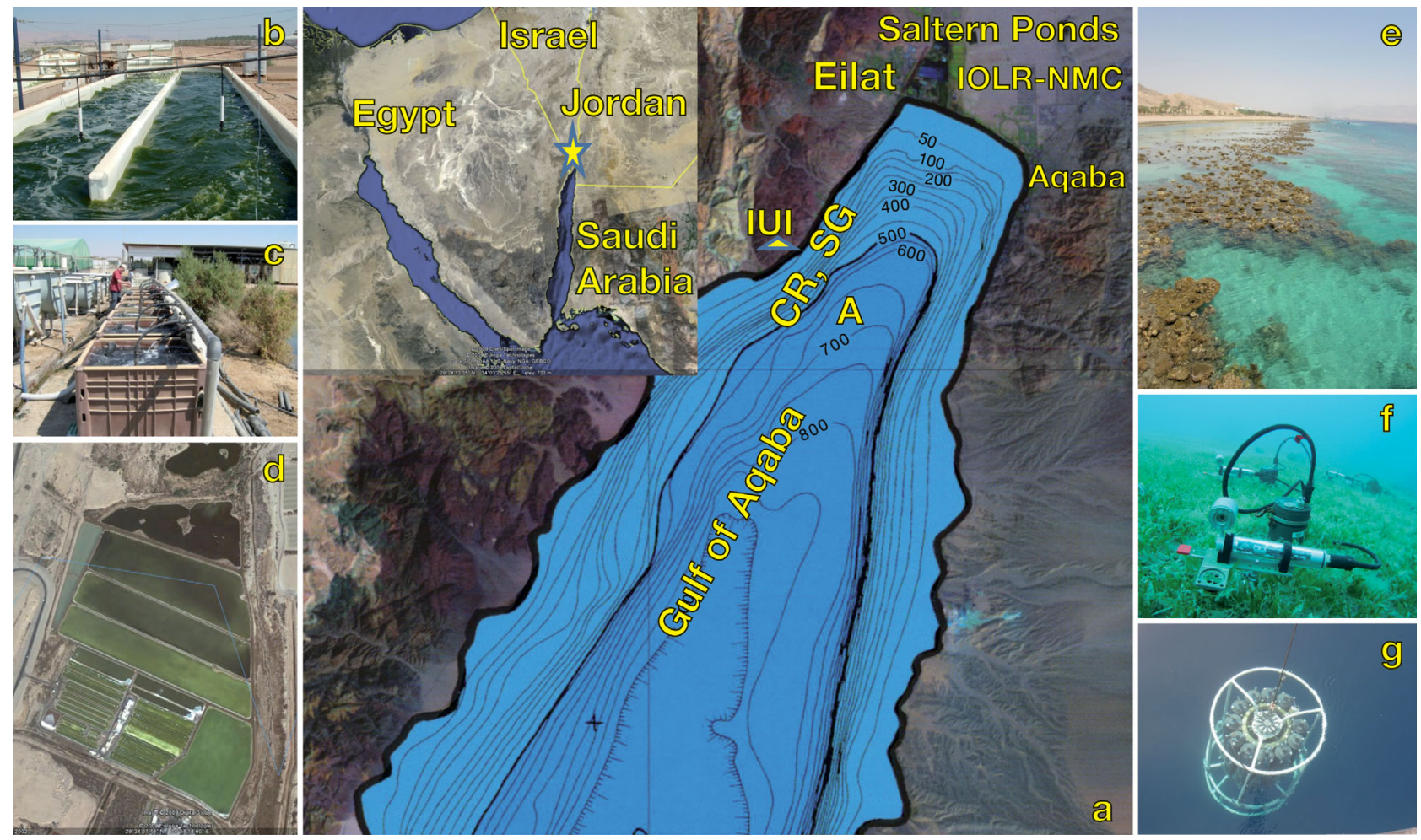

Fig. 1. Location of the 8th GAP workshop. (a) Bathymetric map (centre; depth in m) of the northern Gulf of Aqaba, location of the experimental work groups and the Gulf of Aqaba ( $\boldsymbol{c}_{\text {; }}$ inset). (b) Work on algal biotechnology and (c) macroalgae at the National Mariculture Center of the Israeli Oceanographic and Limnological Research Co (NMC-IOLR). (d) Man-made saltern ponds are located at the northern edge of Eilat. (e) Coral reef (CR in [a]) and (f) seagrass meadows (SG in [a]) are adjacent to the Interuniversity Institute for Marine Sciences (IUI) at Eilat. (g) Open ocean and phytoplankton productivity groups sampled from Station A (A in [a]. Credits: Bathymetric map in (a), J. K. Hall, Geological Survey of Israel (GSI /1812000); map of region in (a) and saltern ponds in (d), Google Earth. Photos: Coral reef in (e), Victor China; seagrass meadow in (f), João Silva; macroalgae tanks in (c),

Felix Figueroa; open ocean in (g), Noga Stambler; algal runways in (b), Shai Gabai

Papers resulting from the work of the macroalgae and seagrass groups during GAP will appear in a special theme section of Aquatic Biology.

The next GAP workshop will be held in June 2011, in Malaga (Spain).

\section{LITERATURE CITED}

Bar-Zeev E, Berman-Frank I, Stambler N, Vázquez Domínguez E and others (2009) Transparent exopolymer particles (TEP) link phytoplankton and bacterial production in the Gulf of Aqaba. Aquat Microb Ecol 56:217-225

- Beardall J, Ihnken S, Quigg A (2009) Gross and net primary production: closing the gap between concepts and measurements. Aquat Microb Ecol 56:113-122

> Dubinsky Z, Stambler N (2009) Photoacclimation processes in phytoplankton: mechanisms, consequences and applications. Aquat Microb Ecol 56:163-176

Iluz D, Dishon G, Capuzzo E, Meeder E and others (2009) Short-term variability in primary productivity during a wind-driven diatom bloom in the Gulf of Eilat (Aqaba). Aquat Microb Ecol 56:205-215

Kromkamp JC, Beardall J, Sukenik A, Kopecký J and others (2009) Short-term variations in photosynthetic parameters of Nannochloropsis cultures grown in two types of out- door mass cultivation systems. Aquat Microb Ecol 56: 309-322

Lis H, Shaked Y (2009) Probing the bioavailability of organically bound iron: a case study in the Synechococcus-rich waters of the Gulf of Aqaba. Aquat Microb Ecol 56: 241-253

> Luz B, Barkan E (2009) Net and gross oxygen production from $\mathrm{O}_{2} / \mathrm{Ar}_{,}{ }^{17} \mathrm{O} /{ }^{16} \mathrm{O}$ and ${ }^{18} \mathrm{O} /{ }^{16} \mathrm{O}$ ratios. Aquat Microb Ecol 56: $133-145$

> Marra J (2009) Net and gross productivity: weighing in with ${ }^{14} \mathrm{C}$. Aquat Microb Ecol 56:123-131

> Oren A (2009) Saltern evaporation ponds as model systems for the study of primary production processes under hypersaline conditions. Aquat Microb Ecol 56:193-204

> Prášil O, Bína D, Medová H, Reháková K, Zapomělová E, Veselá J, Oren A (2009) Emission spectroscopy and kinetic fluorometry studies of phototrophic microbial communities along a salinity gradient in solar saltern evaporation ponds of Eilat, Israel. Aquat Microb Ecol 56:285-296

- Raven JA (2009) Contributions of anoxygenic and oxygenic phototrophy and chemolithotrophy to carbon and oxygen fluxes in aquatic environments. Aquat Microb Ecol 56:177-192

> Sørensen K, Řeháková K, Zapomělová E, Oren A (2009) Distribution of benthic phototrophs, sulfate reducers, and methanogens in two adjacent saltern evaporation ponds in Eilat, Israel. Aquat Microb Ecol 56:275-284 
Suggett DJ, MacIntyre HL, Kana TM, Geider RJ (2009a) Comparing electron transport with gas exchange: parameterising exchange rates between alternative photosynthetic currencies for eukaryotic phytoplankton. Aquat Microb Ecol 56:147-162

Suggett DJ, Stambler N, Prášil O, Kolber Z and others (2009b) Nitrogen and phosphorus limitation of oceanic microbial growth during spring in the Gulf of Aqaba. Aquat Microb Ecol 56:227-239

Sukenik A, Beardall J, Kromkamp JC, Kopecký J and others (2009) Photosynthetic performance of outdoor Nan- nochloropsis mass cultures under a wide range of environmental conditions. Aquat Microb Ecol 56: 297-308

Warkentin M, Schumann R, Oren A (2009) Community respiration studies in saltern crystallizer ponds. Aquat Microb Ecol 56:255-261

Woelfel J, Sørensen K, Warkentin M, Forster S, Oren A, Schumann R (2009) Oxygen evolution in a hypersaline crust: in situ photosythesis quantification by microelectrode profiling and use of planar optode spots in incubation chambers. Aquat Microb Ecol 56:263-273 